\title{
Effects of Monotypic and Binary Mixtures of Metal Oxide Nanoparticles on Microbial Growth in Sandy Soil Collected from Artificial Recharge Sites
}

\author{
Kyung-Seok Ko ${ }^{1}$, Kyoochul Ha ${ }^{1}$ and In Chul Kong ${ }^{2, *}$ \\ Received: 23 September 2015; Accepted: 17 November 2015; Published: 24 November 2015 \\ Academic Editor: Michael Routledge \\ 1 Groundwater Department, Geologic Environment Division, Korea Institute of Geoscience and Mineral \\ Resources (KIGAM), Daejeon 34132, Korea; kyungsok@kigam.re.kr (K.-S.K.); hasife@kigam.re.kr (K.H.) \\ 2 Department of Environmental Engineering, Yeungnam University, Gyeongbuk 38541, Korea \\ * Correspondence: ickong@ynu.ac.kr; Tel.: +82-53-810-2546
}

\begin{abstract}
The potential effects of monotypic and binary metal oxide nanoparticles (NPs, $\mathrm{ZnO}$, $\mathrm{NiO}, \mathrm{Co}_{3} \mathrm{O}_{4}$ and $\mathrm{TiO}_{2}$ ) on microbial growth were evaluated in sandy soil collected from artificial recharge sites. Microbial growth was assessed based on adenosine triphosphate (ATP) content, dehydrogenase activity (DHA), and viable cell counts (VCC). Microbial growth based on ATP content and VCC showed considerable differences depending on NP type and concentration, whereas DHA did not significantly change. In general, $\mathrm{ZnO}$ NPs showed the strongest effect on microbial growth in all measurements, showing an $\mathrm{EC}_{50}$ value of $10.9 \mathrm{mg} / \mathrm{L}$ for ATP content. The ranking $\left(\mathrm{EC}_{50}\right)$ of NPs based on their effect on microbial growth assessed by ATP content and VCC was $\mathrm{ZnO}>\mathrm{Co}_{3} \mathrm{O}_{4}>\mathrm{NiO}>\mathrm{TiO}_{2}$. Upon exposure to binary NP mixtures, synergistic and additive modes of action were observed for ATP content and VCC, respectively. The ranges of observed $(\mathrm{P}(\mathrm{O}))$ and expected $(\mathrm{P}(\mathrm{E}))$ activity were $83 \%-92 \%$ and $78 \%-82 \%$ of the control ( $p$-value 0.0010 ) based on ATP content and $78 \%-95 \%$ and $72 \%-94 \%$ of the control ( $p$-value 0.8813 ) based on VCC under the tested conditions, respectively. The results indicate that the effects of NP mixtures on microbial growth in the sandy soil matrix were as great, or greater, than those of single NPs. Therefore, understanding the effects of single NPs and NP mixtures is essential for proper ecological risk assessment. Additionally, these findings demonstrate that the evaluation of NP effects may be profoundly influenced by the method of microbial growth measurement.
\end{abstract}

Keywords: ATP; DHA; nanoparticles; microbial growth; mixture; soil; VCC

\section{Introduction}

Engineered artificial recharge systems are achieved by ponding or flowing water onto the soil surface to augment groundwater water resources [1]. The most likely reason for failure of infiltration is clogging. Clogging of artificial recharge systems is generally caused by interdependent mechanisms (physical, chemical, and biological processes). However, clogging likely occurs due to microbiological growth, such as biofilms, on the infiltration surface [2]. Extracellular polysaccharides (EPS), which are key components of the microbial matrix, mediate bacterial adhesion to the surface, provide mechanical stability to the biofilm, and protect cells against external aggression [3].

These days, many products from nanotechnology are available in the fields of electronics, optics, food packaging, textiles, medical devices, cosmetics, fuel cells, catalysts, biosensors, and components for environmental treatment [4]. Due to rapid nanotechnology development, nanoparticles (NPs) have been increasingly used for industrial applications and will inevitably enter natural ecosystems, with soil predicted to be a substantial sink [5]. Therefore, the production, use, and disposal 
of NPs have inevitably led to their release into the environment through atmospheric emissions, domestic wastewater, and agriculture byproducts, either accidentally through manufacturing and transport or intentional release. However, there are a lack of quantitative knowledge and appropriate methods for detecting and quantifying NPs in complex natural media [6]. NPs are generally classified into four categories: (1) carbon-based materials; (2) metal-based materials; (3) dendrimers; and (4) composites [7]. Their unique physicochemical properties (e.g., extremely small size, surface characteristics, reactivity, conductivity, optical sensitivity, etc.) are often associated with unique adverse biological effects in ecosystems [8-12]. Regarding NPs of silver, platinum, and carbon nanotubes, there have been several reports of their toxic effects on terrestrial animals and bacteria $[13,14]$. NPs may exhibit different toxicological effects according to particle variety and size, test organism species, and test method [15].

The environment is generally exposed to complex mixtures of contaminants, but most studies have mainly focused on the effect of single contaminants under laboratory conditions [16]. Therefore, studies on the mixture effects rather than single ones more realistically reflect ecosystem pollution. Unfortunately, predicting the response of an organism by more than one potentially toxic chemical is one of the most difficult matters in environmental risk assessment [17]. In order to solve this problem, mixture models can be used and generally classified into two basic types: concentration addition models and response (effects) addition models. Additionally, the theoretically expected effects of binary mixtures on test organisms can be calculated using a simple mathematical model based on the theory of probabilities [18] or by using the toxic unit (TU) approach [19], which is mostly used to examine mixtures [20,21]. The mixture effect is, thus, defined as being either similar to (additive), greater than (synergistic), or less than (antagonistic) additive in relation to theoretically expected effects calculated based on individual chemicals.

Biomass can be measured by various indirect methods, such as measurement of ATP content and DHA, which are common methods for environmental samples. Cellular ATP is commonly measured based on the production of bioluminescence by a luciferin-luciferase reaction [22]. Dehydrogenase enzyme activity is also an appropriate measure of biological activity and an indirect indicator for environmental samples [23]. In addition, classical heterotrophic plate counting (VCC) is a direct method involving the detachment of microorganisms from the surface and then counting culturable cells on solid media. Recently newly developed techniques are reported for the monitoring of the microbial growth in environmental systems $[24,25]$.

In this study, the inhibitory effects of single and binary mixtures of metal oxide NPs on microbial growth were examined using sandy soil collected from artificial recharge sites. Moreover, the effects of NPs on microbial growth were evaluated using three different methods (ATP, DHA, and VCC) of biomass measurement.

\section{Results}

\subsection{Effects of Single NPs on Microbial Growth}

After initial definitive tests, different concentration ranges of each type of NP were used to evaluate the effects on microbial growth on sandy soil. Microbial growth was determined using both indirect (ATP content and DHA) and direct (VCC) methods. For a control without NP exposure, the quantities of ATP, DHA, and VCC from microbial growth on the soil surface were in the ranges of $7.13 \pm 0.25 \sim 7.75 \pm 0.68 \mathrm{ng}$ ATP/g soil, $16.25 \pm 0.485 \sim 16.13 \pm 0.462 \mu \mathrm{g} / \mathrm{g}$ soil, and $3.28 \times 10^{7} \mathrm{CFU} / \mathrm{g}$ soil, respectively, depending on the batch set. Profiles of ATP content in the presence of NPs are shown in Figure 1. No stimulation of microbial growth was observed under the tested NP concentrations. Weak or no inhibition was observed at the lowest concentration tested for each NP (10 mg/L of $\mathrm{NiO}\left(100 \%\right.$ of control), $\mathrm{Co}_{3} \mathrm{O}_{4}(101 \%$ of control), and $300 \mathrm{mg} / \mathrm{L} \mathrm{TiO} 2$ (90\% of control)), whereas considerable inhibition was observed at $10 \mathrm{mg} / \mathrm{L}$ of $\mathrm{ZnO}(52 \%$ of control). Relative ATP content and VCC were observed to be in the ranges of $101 \%\left(10 \mathrm{mg} / \mathrm{L}\right.$ of $\left.\mathrm{Co}_{3} \mathrm{O}_{4}\right),-9 \%(300 \mathrm{mg} / \mathrm{L}$ of 
$\mathrm{ZnO}$ ), $111 \%$ (300 mg/L of $\mathrm{TiO}_{2}$ ), and $-38 \%$ (300 mg/L of $\mathrm{ZnO}$ ) of the control, respectively (Figure 1). However, in the case of DHA observation, the highest inhibition was $61 \%$ of the control at $300 \mathrm{mg} / \mathrm{L}$ of $\mathrm{NiO}$ (Figure 1).
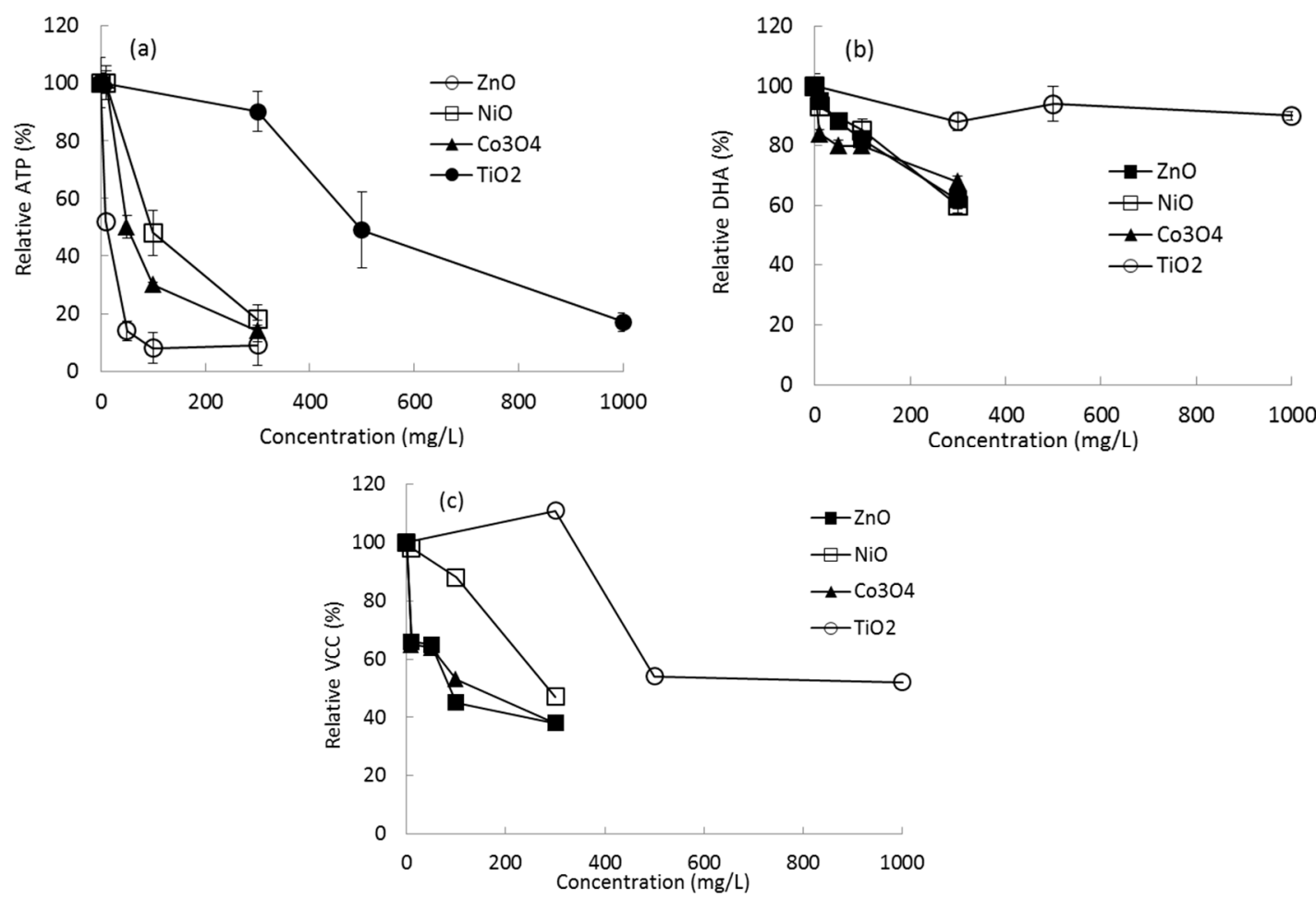

Figure 1. Effects of NPs on microbial growth on sandy soil based on relative (a) ATP content; (b) DHA; and (c) VCC.

Based on these results, the effects of the NPs on microbial growth were evaluated according to their $\mathrm{EC}_{50}$ values, which were calculated using the SPERMAN program (Table 1). $\mathrm{EC}_{50}$ values for DHA were not feasibly calculated because all $\mathrm{EC}_{50 \mathrm{~s}}$ exceeded the tested maximum concentration ( $>300 \mathrm{mg} / \mathrm{L}$ for $\mathrm{NiO}, \mathrm{ZnO}$, and $\mathrm{Co}_{3} \mathrm{O}_{4} ;>1000 \mathrm{mg} / \mathrm{L}$ for $\mathrm{TiO}_{2}$ ). $\mathrm{EC}_{50}$ values based on ATP content were observed to be in the range of $11 \mathrm{mg} / \mathrm{L}(\mathrm{ZnO})$ to $530 \mathrm{mg} / \mathrm{L}\left(\mathrm{TiO}_{2}\right)$. The ranking of NP inhibition $\left(\mathrm{EC}_{50}\right)$ in terms of either ATP content or VCC was in the same order: $\mathrm{ZnO}>\mathrm{Co}_{3} \mathrm{O}_{4}>\mathrm{NiO}>\mathrm{TiO}_{2}$. Among the tested NPs, $\mathrm{ZnO}$ showed the strongest inhibition against microbial growth on sandy soil based on ATP content $\left(\mathrm{EC}_{50}\right.$ of $\left.11 \mathrm{mg} / \mathrm{L}\right)$ or on VCC $\left(\mathrm{EC}_{50}\right.$ of $\left.17.6 \mathrm{mg} / \mathrm{L}\right)$ (Table 1). In terms of ATP content, this value is approximately 48 times less than that of $\mathrm{TiO}_{2}$, which showed the weakest inhibition among the tested NPs.

Table 1. Comparisons of NP toxicity on microbial growth on sandy soil (95\% confidence level).

\begin{tabular}{ccccc}
\hline \multirow{2}{*}{ Methods } & \multicolumn{4}{c}{ Nanoparticle $\mathbf{E C}_{50}(\mathbf{m g} / \mathrm{L})$} \\
\cline { 2 - 5 } & $\mathbf{N i O}$ & $\mathbf{Z n O}$ & $\mathbf{C o}_{\mathbf{3}} \mathbf{O}_{\mathbf{4}}$ & $\mathbf{T i O}_{\mathbf{2}}$ \\
\hline ATP & $87(64.6-116.4)^{\mathbf{a}}$ & $11(7.3-16.3)$ & $55(44.6-66.1)$ & $530(479.1-587.1)$ \\
DHA & $>300$ & $>300$ & $>300$ & $>1000$ \\
VCC & $277(216.0-354.8)$ & $17.6(12.74-24.30)$ & $127(81.0-198.3)$ & $>1000$ \\
\hline \multicolumn{4}{c}{}
\end{tabular}

${ }^{a}$ Value is the range of the $95 \%$ confidence level (low limit-high limit). 


\subsection{Effects of Binary NP Mixtures on Microbial Growth}

The effects of binary mixtures on microbial growth on sandy soil were investigated using four NPs $\left(\mathrm{ZnO}, \mathrm{Co}_{3} \mathrm{O}_{4}, \mathrm{NiO}\right.$, and $\left.\mathrm{TiO}_{2}\right)$ based on ATP and VCC measurements. Each NP type was tested at one concentration (10 mg/L $\mathrm{ZnO}, 70 \mathrm{mg} / \mathrm{L} \mathrm{NiO}, 30 \mathrm{mg} / \mathrm{L} \mathrm{Co}_{3} \mathrm{O}_{4}$, and $500 \mathrm{mg} / \mathrm{L} \mathrm{TiO} 2$ ) similar to the $\mathrm{EC}_{50}$ value of single NPs based on ATP measurement (Table 2). The ATP content and VCC of sandy soil exposed to single and binary NP mixtures after 30 days are shown in Figure 2. The control (no NP amendment) showed a mean ATP level of approximately $7.3 \pm 0.06 \mathrm{ng}$ ATP/g soil after 30 days of incubation, whereas sets amended with single or binary NP mixtures showed ATP levels of 3.1-3.8 and $0.53-1.26 \mathrm{ng}$ ATP $/ \mathrm{g}$, respectively, corresponding to $42 \%-52 \%$ and $7.3 \%-17.3 \%$ of the control. In the case of VCC, the single and binary NP mixture values were $23 \%-58 \%$ and $5 \%-22 \%$ of the control, respectively.
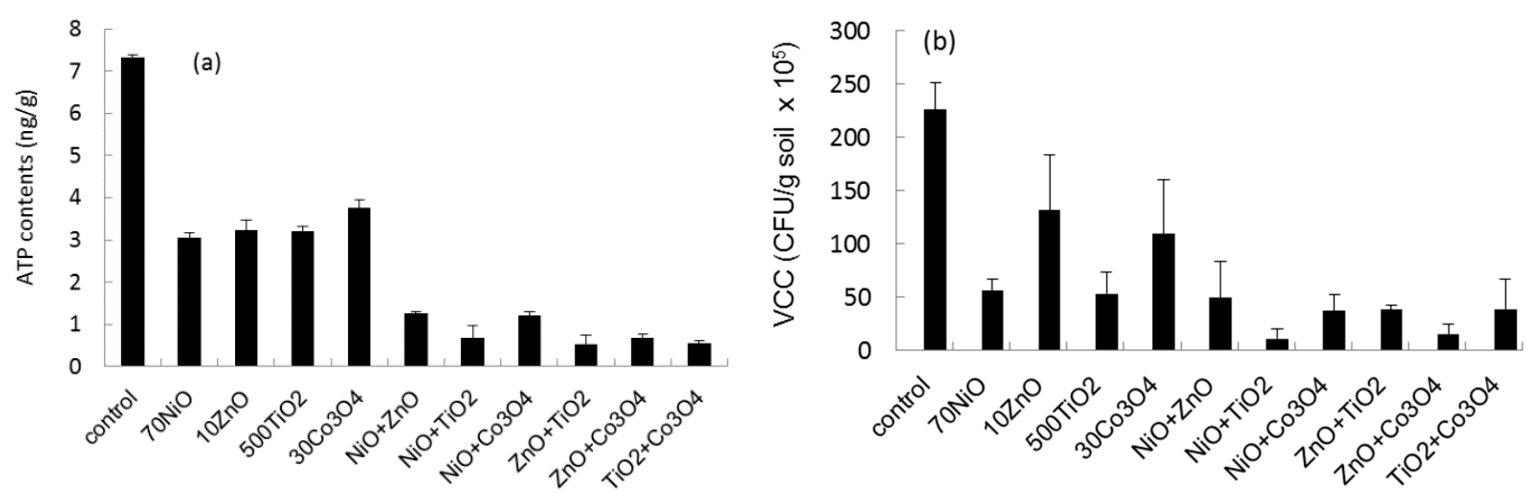

Figure 2. Profiles of (a) ATP content and (b) VCC in the presence of monotypic and binary mixtures of $\mathrm{ZnO}, \mathrm{NiO}, \mathrm{Co}_{3} \mathrm{O}_{4}$, and $\mathrm{TiO}_{2}$.

The observed inhibitory effect, $\mathrm{P}(\mathrm{O})$, of a binary equal mixture was compared with its expected inhibitory effect, $\mathrm{P}(\mathrm{E})$, which was theoretically calculated based on two measurements of single effects using the theory of probabilities (Figure 3). The observed ATP content of the binary mixture was in the range of $8 \%-17 \%$ of the control (no NP amendment), whereas the expected value was in the range of $18 \%-22 \%$ of the control. Comparisons between $\mathrm{P}(\mathrm{O})$ and $\mathrm{P}(\mathrm{E})$ for the ATP observations are shown in Figure 3. In the case of ATP inhibition, $\mathrm{P}(\mathrm{O})$ and $\mathrm{P}(\mathrm{E})$ were $83 \%-93 \%$ and $78 \%-82 \%$ of the control, respectively. Statistically significant differences between $\mathrm{P}(\mathrm{O})$ and $\mathrm{P}(\mathrm{E})$ were observed in ATP content ( $p$-value $=0.001)$. In the case of VCC inhibition, $\mathrm{P}(\mathrm{O})$ and $\mathrm{P}(\mathrm{E})$ were $78 \%-93 \%$ and $72 \%-94 \%$ of the control (Figure 3). There were no significant differences between $\mathrm{P}(\mathrm{E})$ and $\mathrm{P}(\mathrm{O})(p$-value $=0.8813)$.
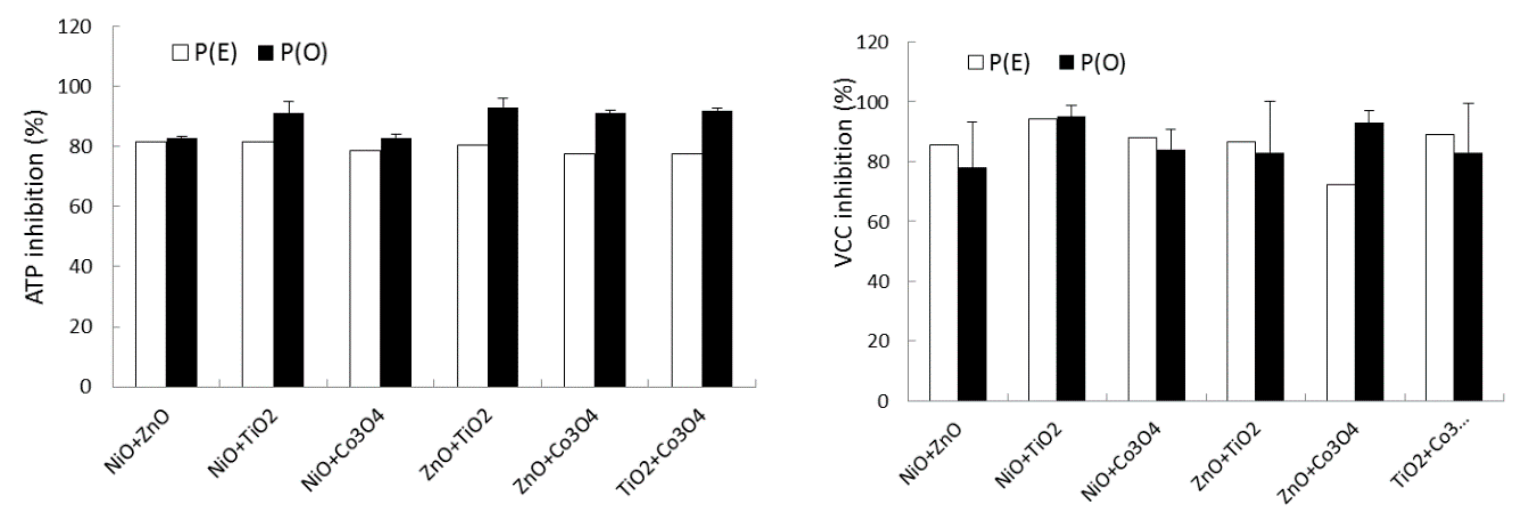

Figure 3. Comparisons of $\mathrm{P}(\mathrm{O})$ and $\mathrm{P}(\mathrm{E})$ for binary NP mixtures based on ATP content and VCC. 
Metal ions released from amended NPs in solutions of single and binary NP mixtures were measured after 30 days (Table 2). The concentration (\%) of metal ions released from the tested NPs in sandy soil slurry ranged from a maximum of $6 \%$ to a minimum of $<0.02 \%$ of the amended $\mathrm{NP}$ concentration. In the case of sets with $10 \mathrm{mg} / \mathrm{L}$ of $\mathrm{ZnO}, 70 \mathrm{mg} / \mathrm{L}$ of $\mathrm{NiO}, 30 \mathrm{mg} / \mathrm{L}$ of $\mathrm{Co}_{3} \mathrm{O}_{4}$, and $500 \mathrm{mg} / \mathrm{L}$ of $\mathrm{TiO}_{2}$, for monotypic NPs or mixtures, the metal ion ranges were as follows: $0.366-0.603 \mathrm{mg} \mathrm{Zn/L,} \mathrm{2.024-2.952} \mathrm{mg} \mathrm{Ni/L,} \mathrm{0.042-0.082} \mathrm{mg} \mathrm{Co/L,} \mathrm{and} \mathrm{0.016-0.065} \mathrm{mg} \mathrm{Ti/L,}$ corresponding to $3.66 \%-6.03 \%, 2.89 \%-4.22 \%, 0.14 \%-0.27 \%$, and $0.003 \%-0.013 \%$, respectively.

Table 2. Metal ion concentration in sandy soil slurry solution after 30 days of incubation.

\begin{tabular}{cccc}
\hline NPs (mg/L) & Metal Ion $(\mathbf{m g} / \mathbf{L})$ & NPs $(\mathbf{m g} / \mathbf{L})$ & Metal Ion $(\mathbf{m g} / \mathrm{L})$ \\
\hline $\mathrm{ZnO}(10)$ & $0.60 \pm 0.065$ & $\mathrm{NiO}+\mathrm{TiO}_{2}(70+500)$ & $2.024 / 0.054$ \\
$\mathrm{Co}_{3} \mathrm{O}_{4}(30)$ & $0.04 \pm 0.015$ & $\mathrm{NiO}+\mathrm{Co}_{3} \mathrm{O}_{4}(70+30)$ & $2.524 / 0.042$ \\
$\mathrm{NiO}(70)$ & $2.95 \pm 0.416$ & $\mathrm{ZnO}+\mathrm{TiO}_{2}(10+500)$ & $0.387 / 0.054$ \\
$\mathrm{TiO}_{2}(500)$ & $0.07 \pm 0.016$ & $\mathrm{ZnO}+\mathrm{Co}_{3} \mathrm{O}_{4}(10+30)$ & $0.616 / 0.082$ \\
$\mathrm{NiO}+\mathrm{ZnO}(70+10)$ & $2.23 \pm 0.366$ & $\mathrm{TiO}_{2}+\mathrm{Co}_{3} \mathrm{O}_{4}(500+30)$ & $0.016 / 0.079$ \\
\hline
\end{tabular}

\section{Discussion}

In this investigation, the effects of monotypic NPs and binary NP mixtures on microbial growth in sandy soil were examined after 30 days of incubation. To facilitate the study of bacterial attachment, a variety of direct and indirect experimental observation methods have been developed [26]. ATP is an energy carrier present in all active cells and is used to measure the amount of active biomass. ATP bioluminescence has been proposed as a technique for estimating microbial activity in a biological process since 1960 [27]. In general, classical heterotrophic plate counting (VCC) includes only culturable cells, whereas ATP measurement also includes bacteria that do not contribute to these counts. The ATP method has been criticized due to the wide variance between ATP content and biomass, however it does hold promise due to its small sample requirement, large number of replicates, and rapid rate [27]. Some researchers have reported that standard plate count methods provide an inaccurate estimate of the number of microorganisms in samples and therefore cannot be used in quantitative measurements [28]. DHA could serve as an indirect indicator of microbial activity in various microbial systems [29]. In this investigation, the effects of NPs on microbial growth on sandy soil were evaluated using indirect (ATP content and DHA) and direct (VCC) measurements.

In a control without NP exposure, ATP, DHA, and VCC in microbial growth on the soil surface were in the ranges of 7.71-12.36 ng ATP/g soil, 17.10-37.35 $\mu \mathrm{g} / \mathrm{g}$ soil, and $1.53 \times 10^{7}-6.28 \times 10^{7} \mathrm{CFU} / \mathrm{g}$ soil, respectively. Generally, investigators have reported that microorganisms produce $10^{-8}$ to $10^{-9} \mu \mathrm{g}$ ATP/cell [27]. Based on this report, the biomass calculated from ATP content was slightly less than that based on VCC. ATP quantities may differ depending on the culture conditions. For example, bacteria in drinking water typically have stable ATP/cell values in the range of $0.7 \times 10^{-7}-2.3 \times 10^{-7} \mathrm{ng}$ ATP/cell $[30,31]$. Therefore, both results present reasonably similar corresponding quantities of biomass.

Based on a preliminary test, different concentration ranges of NPs were adopted for the investigation: $10-300 \mathrm{mg} / \mathrm{L}$ of $\mathrm{ZnO}, \mathrm{NiO}$, and $\mathrm{Co}_{3} \mathrm{O}_{4}$ and $300-1000 \mathrm{mg} / \mathrm{L}$ of $\mathrm{TiO}_{2}$. In general, no stimulation of microbial growth was observed at the tested NP concentrations. The experimental results showed that ATP content and VCC were significantly different according to NP dose and type but not DHA. In the presence of various concentrations of $\mathrm{ZnO}, \mathrm{NiO}, \mathrm{Co}_{3} \mathrm{O}_{4}$, and $\mathrm{TiO}_{2}$ individually, the highest inhibition of microbial growth was observed at $300 \mathrm{mg} / \mathrm{L}$ of $\mathrm{ZnO}$, showing $0.71 \pm 0.53 \mathrm{ng}$ of ATP (91\% inhibition) and $1.24 \times 10^{7} \mathrm{CFU}$ (62\% inhibition) per g of sandy soil. Relatively low inhibition of DHA was observed (10\%-40\% inhibition for all NPs) under all conditions. At the highest tested concentrations ( $300 \mathrm{mg} / \mathrm{L}$ of $\mathrm{ZnO}, \mathrm{NiO}$, and $\mathrm{Co}_{3} \mathrm{O}_{4}$ and $1000 \mathrm{mg} / \mathrm{L}$ of $\mathrm{TiO}_{2}$ ), all the tested NPs showed significant reduction of microbial growth $(82 \%-91 \%$ and $48 \%-96 \%$ relative inhibition of ATP and VCC, respectively). With respect to sensitivity ( $\mathrm{EC}_{50}$ values), the order of microbial growth 
inhibition of the NPs based on ATP and VCC was as follows: $\mathrm{ZnO}>\mathrm{Co}_{3} \mathrm{O}_{4}>\mathrm{NiO}>\mathrm{TiO}_{2}$. The $\mathrm{EC}_{50}$ values for DHA were all higher than the tested maximum concentration of each NP. In terms of ATP content, the $\mathrm{EC}_{50}$ of toxic $\mathrm{ZnO}$ was approximately 50 -fold lower than that of $\mathrm{TiO}_{2}$, which was the least toxic NP. In a previous report on NP toxicity, $\mathrm{ZnO}$ also showed higher toxicity than NPs of NiO, $\mathrm{Co}_{3} \mathrm{O}_{4}$, and $\mathrm{TiO}_{2}$ in terms of bacterial bioluminescence activity and seed germination [32].

No single observation may show uniform inhibition and sensitivity to chemicals. ATP-based observations are used routinely to detect bacteria because ATP concentrations are relatively constant across many different growth conditions [33]. Sule et al. [33] reported that an ATP assay, crystal violet assay, and scanning electron microscopy yielded similar results for six of eight strains tested. In this investigation, both ATP and VCC showed considerable sensitivity based on the conditions and type of NP. However, researchers have reported that VCC measurements may have the following limitations: (1) ineffective at removing adhered cells, making counts on agar plates inconsistent with the actual number of bacteria adhered to the surface; (2) some biofilm systems and cultivation conditions may induce cells into a "viable but nonculturable" state in which they are metabolically active but unable to divide and form colonies in culture medium, probably as a survival mechanism in response to adverse conditions $[34,35]$. The reason why the results for DHA were insensitive compared to those for ATP and VCC is not clear at this point, but enzymatic activity may be dependent on the type of matrix. For example, dehydrogenases and acid phosphatases exhibit greater activity in heavy loamy sand, whereas their activity is not greater in silty sandy loam [23]. In our previous investigation using compost samples, insensitive DHA patterns were also observed for various compost samples, whereas the ATP content of the samples differed considerably depending on the conditions [36]. Therefore, DHA might not correlate well with the biomass content in biofilm because DHA activity can vary depending on the physiological conditions in a microbial system composed of various microbial species [37]. Based on the results from all three assays, a combination of ATP and VCC assays appears to be the most effective quantitative measurement of the effects of NPs on microbial growth on sandy soil. The data obtained from the ATP assays in this study also showed patterns similar to those of total microbial biomass and VCC.

Although their precise toxicity mechanisms are largely unknown, studies have shown that the toxicity of NPs is generally governed by properties such as particle size, shape, and surface properties $[38,39]$. Some studies reported that the effects of NPs on bacteria could be occurred by mechanisms, such as membrane disorganization, DNA damage, surface photocatalytic oxidation, and reactive oxygen species (ROS) production [40-43]. NPs also may undergo agglomeration, sorption, desorption, dissolution, and migration in different soils with different textures, $\mathrm{pHs}$, ionic strengths, and organic matter content. NPs may vary in bioavailability and alter soil microorganisms' exposure to them [44]. Dhas et al. [45] reported that Ag and ZnO NPs disrupt the cell membrane of bacterial cells by making pits in it due to their small size, leading to increased membrane permeability and cell death. Tong et al. [46] and Marambio-Jones and Hoek [47] reported that the toxicity of Ag NPs is mainly due to the effects of free ions. On the other hand, $\mathrm{TiO}_{2} \mathrm{NPs}$ are chemically stable, and their toxicity is predominantly caused by ROS generation with ultraband gap excitation. The antimicrobial activity of NPs may also be related to their positively charged surface. Electrostatic force might contribute greatly to the adhesion of positively charged particles [45]. The antibacterial mechanism of $\mathrm{ZnO}$ nanoparticles is most likely due to disruption of the cell membrane, which affects its permeability [48]. Lopes et al. [49] reported that dissolution and particle size in daphnia test media were to be essential to NP toxicity. At this point, it is not clear whether the toxicity was induced by the particles or by released ions. In our further investigation, the effect of metal ion concentration $\left(0.6 \mathrm{mg} \mathrm{Zn} / \mathrm{L}\right.$ of $\mathrm{ZnCl}_{2}$ and $2.95 \mathrm{mg} \mathrm{Ni} / \mathrm{L}$ of $\mathrm{NiCl}_{2}$ ) of $10 \mathrm{mg} / \mathrm{L} \mathrm{ZnO}$ and $70 \mathrm{mg} / \mathrm{L} \mathrm{NiO}$ was evaluated based on bacterial bioluminescent activity, which showed approximately $20 \%$ and $25 \%$ inhibition of control, respectively. Therefore, the toxicity might be induced both by the particles and by released ion concentration, which will be depended on tested conditions. 
The effects of binary mixtures of NPs on microbial growth were investigated based on ATP and VCC measurements. A binary mixture may show three different effects, such as antagonistic (less than additive), synergistic (greater than additive), and additive effects [50]. The activity of the binary NP mixtures was in the range of $7 \%-17 \%$ and $5 \%-22 \%$ of the control based on ATP content and VCC, respectively. Expected mixture effects were determined based on the theory of probabilities [18]. Based on the theory of probabilities, statistically significant differences between $P(E)$ and $P(O)$ were observed for ATP observation $(\mathrm{P}(\mathrm{O})>\mathrm{P}(\mathrm{E}) ; p$-value $=0.0010)$, whereas no significant differences were observed for VCC observation $(\mathrm{P}(\mathrm{O}) \approx \mathrm{P}(\mathrm{E}) ; p$-value $=0.8813)$. This result indicates that contaminating NP mixtures may have synergistic or at least additive effects on an ecosystem.

The present work demonstrated that mixtures of the tested NPs could show particular modes of action, synergistic or additive effects, depending on the method of biomass measurement. This result indicated that one method of biomass measurement could not provide results equivalent to those of another one. Therefore, combining results (e.g., ATP and VCC measurements) as opposed to just using a single method is a better strategy for the bioassessment of the effects of NPs on microbial growth. Clearly, more work needs to be conducted to understand the mechanism of action of monotypic NPs and NP mixtures in environmental samples.

\section{Materials and Methods}

\subsection{Soil and Inoculant Source Characteristics}

Soil samples were collected from artificial recharge sites near the Nakdong river in Korea. Five samples from each site were collected, and the mixture was used as a test soil sample. Characteristics of sandy soil are presented in Table 3. Pond water was used as a microbial inoculant source for biofilm formation on the sandy soil. The average characteristics of the pond water (inoculant source) were as follows: T-N $155 \mathrm{mg} / \mathrm{L}, \mathrm{COD}_{\mathrm{Mn}} 4.6 \mathrm{mg} / \mathrm{L}, \mathrm{pH} 7.8$, and total coliforms $1300 \mathrm{MPN} / 100 \mathrm{~mL}$. Results of each condition were compared based on relative value of control set.

Table 3. Characteristics of the sandy soil used in this study.

\begin{tabular}{cccc}
\hline Parameter & Value & Soil Particle Size $(\mathbf{m m})$ & Proportion $\mathbf{( \% \mathbf { w t } . )}$ \\
\hline organic matter $(\%)$ & 0.30 & fine sand $(<0.300)$ & 13.2 \\
$\mathrm{pH}$ & 6.41 & medium sand $(0.3-1.7)$ & 80.8 \\
bulk density $\left(\mathrm{g} / \mathrm{cm}^{3}\right)$ & 1.647 & coarse sand $(>1.7)$ & 6.0 \\
porosity & 0.39 & & \\
\hline
\end{tabular}

\subsection{Experimental Setup for Microbial Growth and the Effects of NPs}

The optimum conditions for batch microbial growth on sandy soil were determined based on preliminary tests under several conditions, including batch incubation period, inoculant type, nutrients, etc. A mixture composed of $20 \mathrm{~g}$ of air-dried soil, $5 \mathrm{~mL}$ of pond water (inoculation source), and $45 \mathrm{~mL}$ of minimum salt medium (MSM) with $0.1 \%$ yeast extract was incubated for 30 days at $25^{\circ} \mathrm{C}$ and $130 \mathrm{rpm}$. MSM was composed of $0.2 \mathrm{~g}$ of $\mathrm{MgSO}_{4} \cdot 7 \mathrm{H}_{2} \mathrm{O}, 0.1 \mathrm{~g}$ of $\mathrm{CaCl}_{2}, 0.05 \mathrm{mg}$ of $\mathrm{FeSO}_{4} \cdot 7 \mathrm{H}_{2} \mathrm{O}$, $0.25 \mathrm{mg}$ of $\mathrm{NaM}_{\mathrm{O}} \mathrm{O}_{4} \cdot 2 \mathrm{H}_{2} \mathrm{O}, 0.43 \mathrm{~g}$ of $\mathrm{K}_{2} \mathrm{HPO}_{4}, 0.23 \mathrm{~g}$ of $\mathrm{KH}_{2} \mathrm{PO}_{4}$, and $1000 \mathrm{~mL}$ of distilled water.

The effects of NPs on microbial growth were individually assessed at concentrations of 0-300 mg/L ( $\mathrm{ZnO}, \mathrm{NiO}$, and $\left.\mathrm{Co}_{3} \mathrm{O}_{4}\right)$ and 0-1000 mg/L ( $\left.\mathrm{TiO}_{2}\right)$. The following concentrations, close to the $\mathrm{EC}_{50}$ of single NPs based on ATP content, were chosen to investigate the effects of binary NP mixtures on microbial growth: $10 \mathrm{mg} / \mathrm{L}$ of $\mathrm{ZnO}, 70 \mathrm{mg} / \mathrm{L}$ of $\mathrm{NiO}, 30 \mathrm{mg} / \mathrm{L}$ of $\mathrm{Co}_{3} \mathrm{O}_{4}$, and $500 \mathrm{mg} / \mathrm{L}$ of $\mathrm{TiO}_{2}$. After 30 days of incubation, microbial growth on the sandy soil was determined based on ATP content, DHA, and VCC. All other measurements were performed using modified standard methods [51]. 


\subsection{Microbial Activity Measurement Based on ATP Content, DHA, and VCC}

For ATP (adenosine triphosphate) measurement, $10 \mathrm{~g}$ of soil sample after 30 days of incubation was washed twice using a $0.85 \% \mathrm{NaCl}$ solution. Prewashed sandy soil and $20 \mathrm{~mL}$ of sterilized $\mathrm{dH}_{2} \mathrm{O}$ was sonicated for $30 \mathrm{~min}$ to extract biomass from it. Distilled water was boiled by heating water on a hot plate, after which $1 \mathrm{~mL}$ of boiling water was added to the centrifuged cell pellet and vortexed. Samples were prepared based on manufacture's protocol (Enliten ATP Assay System, Promega, Madison, WI, USA), ATP content was measured using a Luminometer 20/20 (Turner Design Inc., Sunnyvale, CA, USA).

For DHA measurement, soil samples $(3 \mathrm{~g})$ and $\mathrm{CaCO}_{3}(0.03 \mathrm{~g})$ were mixed by vortexing with $1 \mathrm{~mL}$ of $3 \%$ TTC (2, 3, 5-triphenyl tetrazolium chloride) (Sigma-Aldrich Co., St. Louis, MO, USA), and distilled water $(2.5 \mathrm{~mL})$ was then added and the solution was vortexed again. Following incubation at $37^{\circ} \mathrm{C}$ for $24 \mathrm{~h}, 20 \mathrm{~mL}$ of methanol was added and shaken for $20 \mathrm{~min}$ [51].

For measurement of VCC, $10 \mathrm{~g}$ of soil was mixed with $20 \mathrm{~mL}$ of distilled water and sonicated for $5 \mathrm{~min}$. The extracted biomass were serially diluted and spread on a Petri dish containing $\mathrm{R}_{2} \mathrm{~A}$ solid medium. Colonies were counted following two days of incubation $\left(25^{\circ} \mathrm{C}\right)$.

\subsection{Statistical Analysis and Chemicals}

Four types of NPs were tested in this study. Metal oxide NPs of $\mathrm{TiO}_{2}(<25 \mathrm{~nm}), \mathrm{NiO}(30 \mathrm{~nm})$, and $\mathrm{Co}_{3} \mathrm{O}_{4}(10-30 \mathrm{~nm})$ were obtained from Nanostructured and Amorphous Materials (Houston, TX, USA). Metal oxide ZnO (40-100 nm) was obtained from Alfa Aesar (Ward Hill, MA, USA). To prepare stock solutions of NPs, NPs were suspended directly in deionized water and dispersed by ultrasonic vibration for $10 \mathrm{~min}$ prior to use. All other chemicals were of reagent grade and purchased from Sigma and Aldrich (St. Louis, MO, USA) or Fisher (Pittsburg, PA, USA). All stock NP solutions were dissolved in sterile distilled water. Following incubation, the metal of the amended NPs in solution was analyzed by inductively coupled plasma-optical emission spectrometry (ICP-OES; Perkin-Elmer Optima 7300DV, Waltham, MA, USA).

The $\mathrm{EC}_{50}$ (concentration of a chemical where $50 \%$ of its effect is observed) values of single NPs used for microbial growth were determined using the Trimmed Spearman-Karber method [20]. The SPEARMAN computer program (US EPA's Center for Exposure Assessment Modeling) was used to estimate $\mathrm{EC}_{50}$ values. In the mixture test, the theoretically expected effects of the binary mixtures were evaluated using a simple mathematical model based on the theory of probabilities, which has been used before by several researchers $[18,52]$.

$$
\mathrm{P}(\mathrm{E})=\mathrm{P}_{1}+\mathrm{P}_{2}-\left(\mathrm{P}_{1} \mathrm{P}_{2} / 100\right)
$$

$\mathrm{P}_{1}$ : inhibition caused by chemical " 1 "; $\mathrm{P}_{2}$ : inhibition caused by chemical "2"; $\mathrm{P}(\mathrm{E})$ : theoretically expected inhibition.

The observed inhibition of the binary mixture $\mathrm{P}(\mathrm{O})$ determined by the experiment was compared with the theoretically expected inhibition $\mathrm{P}(\mathrm{E})$ calculated by the above equation. The mode of interaction was characterized as additive when the difference between $\mathrm{P}(\mathrm{O})$ and $\mathrm{P}(\mathrm{E})$ was not significant. The mode of interaction was also characterized as synergistic or antagonistic when the observed value was significantly higher or lower, respectively, than the theoretically predicted value at a $p$ (null hypothesis) $<0.05$ level of significance. The $95 \%$ level of significance of the results was calculated according to Student's $t$-test (http:/ / www.graphpad.com).

Acknowledgments: This research was supported by the Basic Research Project of the Korea Institute of Geoscience and Mineral Resources (KIGAM) funded by the Ministry of Science, ICT and Future Planning of Korea.

Author Contributions: Kyoochul Ha supervised this research; Kyung-Seok Ko and In Chul Kong analyzed the data and wrote the paper.

Conflicts of Interest: The authors declare no conflict of interest. 


\section{References}

1. Bouwer, A. Artificial recharge of groundwater: Hydrogeology and engineering. Hydrogeol. J. 2002, 10, 121-142. [CrossRef]

2. Ye, X.; Du, X.; Li, S.; Yang, Y. Study on closing mechanism and control methods of artificial recharge. In Proceedings of the 2010 International Conference on Challenges in Environmental Science and Computer Engineering, Wuhan, China, 6-7 March 2010; Institute of Electrical and Electronics Engineers (IEEE): New York, NY, USA, 2010; pp. 29-32.

3. Da Silva, E.P.; de Martinis, E.C.P. Current knowledge and perspectives on biofilm formation: The case of Listeria monocytogenes. Appl. Microbiol. Biotechnol. 2013, 97, 957-968. [CrossRef] [PubMed]

4. Stampoulis, D.; Sinha, S.K.; White, J.C. Assay-dependent phytoxicity of nanoparticles to plants. Environ. Sci. Technol. 2009, 43, 9473-9479. [CrossRef] [PubMed]

5. Ge, Y.; Schimel, J.P.; Holden, P.A. Identification of soil bacteria susceptible to $\mathrm{TiO}_{2}$ and $\mathrm{ZnO}$ nanoparticles. Appl. Environ. Microbiol. 2012, 78, 6749-6758. [CrossRef] [PubMed]

6. Gottschalk, F.; Sun, T.Y.; Nowack, B. Environmental concentrations of engineered nanoparticles: Review of modeling and analytical studies. Environ. Pollut. 2013, 181, 287-300. [CrossRef] [PubMed]

7. Lin, D.; Xing, B. Phytotoxicity of nanoparticles: Inhibition of seed germination and root growth. Environ. Pollut. 2007, 150, 243-250. [CrossRef] [PubMed]

8. Nel, A.; Xia, T.; Madler, L.; Li, N. Toxic potential of materials at the nanolevel. Science 2006, 311, $622-627$. [CrossRef] [PubMed]

9. Brunner, T.J.; Wick, P.; Manser, P.; Spohn, P.; Grass, R.N.; Limbach, L.K.; Bruinink, A.; Stark, W.J. In vitro cytotoxicity of oxide nanoparticles: Comparison to asbestos, silica, and the effect of particle solubility. Environ. Sci. Technol. 2006, 40, 4374-4381. [CrossRef] [PubMed]

10. Serpone, N.; Dondi, D.; Albini, A. Inorganic and organic UV filters: Their role and efficacy in sunscreens and suncare product. Inorg. Chim. Acta 2007, 360, 794-802. [CrossRef]

11. Heinlaan, M.; Ivask, A.; Blinova, I.; Dubourguier, H.C.; Kahru, A. Toxicity of nanosized and bulk AnO, $\mathrm{CuO}$ and $\mathrm{TiO}_{2}$ to bacteria Vibrio fischeri and crustaceans Daphnia magna and Thamnocephalus platyurus. Chemosphere 2008, 71, 1308-1316. [CrossRef] [PubMed]

12. Aruoja, V.; Dubourguier, H.C.; Kasemets, K.; Kahru, A. Toxicity of nanoparticles of $\mathrm{CuO}, \mathrm{ZnO}$ and $\mathrm{TiO}_{2}$ to microalgae Pseudokirchneriella subcapitata. Sci. Total Environ. 2009, 407, 1461-1468. [CrossRef] [PubMed]

13. Petersen, E.J.; Pinto, R.A.; Landrum, P.F.; Weber, W.J. Influence of carbon nanotubes on pyrene bioaccumulation from contaminated soils by earthworms. Environ. Sci. Technol. 2009, 43, 4181-4187. [CrossRef] [PubMed]

14. Roh, J.Y.; Sim, S.J.; Yi, J.; Park, K.; Chung, K.H.; Ryu, D.Y.; Choi, J. Ecotoxicity of silver nanoparticles on the soil nematode Caenorhabditis elegans using functional ecotoxicogenomics. Environ. Sci. Technol. 2009, 43, 3933-3940. [CrossRef] [PubMed]

15. Jing, J.; Long, Z.; Lin, D. Toxicity of oxide nanoparticles to the green algae Chlorella sp. Chem. Eng. J. 2010, 170, 525-530.

16. Pavlaki, M.D.; Pereira, R.; Loureiro, S.; Soares, A.M.V.M. Effects of binary mixtures on the life traits of Daphnia magna. Ecotoxicol. Environ. Saf. 2011, 74, 99-110. [CrossRef] [PubMed]

17. Norwood, W.P.; Borgmann, U.; Dixon, D.G.; Wallace, A. Effects of metal mixtures on aquatic biota: A review of observations and methods. Hum. Ecol. Risk Assess. 2003, 9, 795-811. [CrossRef]

18. Kungolos, A.; Emmanouil, C.; Tsiridis, V.; Tsiropoulos, N. Evaluation of toxic and interactive toxic effects of three agrochemicals and copper using a battery of microbiotests. Sci. Total Environ. 2009, 407, 4610-4615. [CrossRef] [PubMed]

19. Horvat, T.; Vidaković-Cifrek, Ž.; Oreščnin, V.; Tkalec, M.; Pevalek-Kozlina, B. Toxicity assessment of heavy metal mixtures by Lemna minor L. Sci. Total Environ. 2007, 384, 229-238. [CrossRef] [PubMed]

20. An, Y.J.; Kim, Y.M.; Kwon, Y.I.; Jeong, S.W. Combined effect of copper, cadmium, and lead upon Cucumis sativus growth and bioaccumulation. Sci. Total Environ. 2004, 326, 857-863. [CrossRef] [PubMed]

21. Van der Geest, H.G.; Greve, G.D.; Boivin, M.E.; Kraak, M.H.S.; van Gestel, C.A.M. Mixture toxicity of copper and diazinon to larvae of the mayfly (Ephoron virgo) judging additivity at different effect levels. Environ. Toxicol. Chem. 2000, 19, 2900-2905. [CrossRef] 
22. Yang, N.C.; Ho, W.M.; Chen, Y.H.; Hu, M.L. A convenient one-step extraction of cellular ATP using boiling water for the luciferin-luciferase assay of ATP. Anal. Biochem. 2002, 306, 323-327. [CrossRef] [PubMed]

23. Wyszkowska, J.; Kucharski, J.; Lajszner, W. Enzymatic activities in different soils contaminated with copper. Polish J. Environ. Stud. 2005, 14, 659-664.

24. Dror-Ehre, A.; Adin, A.; Marlovich, G.; Mamane, H. Control of biofilm formation in water using molecularly capped silver nanoparticles. Water Res. 2010, 44, 2601-2609. [CrossRef] [PubMed]

25. Neu, T.R.; Lawrence, J.R. Innovative techniques, sensors, and approaches for imaging biofilms at different scales. Trends Microbiol. 2015, 23, 233-242. [CrossRef] [PubMed]

26. Djordjevic, D.; Widemann, M.; McLandsborough, L.A. Microtiter plate assay for assessment of Listeria monocytogenes biofilm formation. Appl. Environ. Microbiol. 2002, 68, 2950-2958. [CrossRef] [PubMed]

27. Chu, C.P.; Lee, D.J.; Chang, B.-V.; Liao, C.S. Using ATP bioluminescence technique for monitoring microbial activity in sludge. Biotechnol. Bioeng. 2001, 75, 469-474. [CrossRef] [PubMed]

28. Poulsen, V.L. Microbial biofilm in food processing. LWT Food Sci. Technol. 1999, 32, 321-326. [CrossRef]

29. Irha, N.; Slet, J.; Petersell, V. Effect of heavy metals and PAH on soil assessed via dehydrogenase assay. Environ. Int. 2003, 28, 779-782. [CrossRef]

30. Magic-Knezev, A.; van der Kooij, D. Optimization and significance of ATP analysis for measuring active biomass in granular activated carbon filters used in water treatment. Water Res. 2004, 38, 3971-3979. [CrossRef] [PubMed]

31. Velten, S.; Hammes, F.; Boller, M.; Egli, T. Rapid and direct estimation of active biomass on granular activated carbon through ATP determination. Water Res. 2007, 41, 1973-1983. [CrossRef] [PubMed]

32. Ko, K.-S.; Kong, I.C. Toxic effects of nanoparticles on bioluminescence activity, seed germination, and gene mutation. Appl. Microbiol. Biotechnol. 2014, 98, 3295-3303. [CrossRef] [PubMed]

33. Sule, P.; Wadhawan, T.; Carr, N.J.; Horne, S.M.; Wolfe, A.J.; Prub, B.M. A combination of assays reveals biomass differences in biofilms formed by Escherichia coli mutants. Lett. Appl. Microbiol. 2009, 49, $299-304$. [CrossRef] [PubMed]

34. Besnard, V.; Federighi, M.; Cappelier, J.M. Evidence of viable but non-culturable state in Listeria monocytogenes by direct viable count and CTC-DAPI double staining. Food Microbiol. 2000, 17, 697-704. [CrossRef]

35. Foong, S.C.C.; Dickson, J.S. Survival and recovery of viable but nonculturable Listeria monocytogenes cells in a nutritionally depleted medium. J. Food Prot. 2004, 67, 1641-1645.

36. Kong, I.C. Bioassessments of anaerobically decomposing organic refuse in laboratory lysimeters with and without leachate recycling and pH adjustment. Waste Manag. Res. 2010, 26, 141-148. [CrossRef] [PubMed]

37. Lazarova, V.; Manem, J. Biofilm characterization and activity analysis in water and wastewater treatment. Water Res. 1995, 29, 2227-2245. [CrossRef]

38. Crane, M.; Handy, R.D.; Garrod, J.; Owen, R. Ecotoxicity test methods and environmental hazard assessment for engineered nanoparticles. Ecotoxicology 2008, 17, 421-437. [CrossRef] [PubMed]

39. Navarro, E.; Baun, A.; Behra, R.; Hartmann, N.B.; Filser, J.; Miao, A.J.; Quigg, E.A.; Santschi, P.H.; Sigg, L. Environmental behavior and exotoxicity of engineered nanoparticles to algae, plants, and fungi. Ecotoxicology 2008, 17, 372-386. [CrossRef] [PubMed]

40. Brayner, R.; Ferrari-Iliou, R.; Brivois, N.; Djediat, S.; Benedetti, M.F.; Fiévet, F. Toxicological impact studies based on Escherichia coli bacteria in ultrafine $\mathrm{ZnO}$ nanoparticles colloidal medium. Nano Lett. 2006, 6, 866-870. [CrossRef] [PubMed]

41. Choi, O.; Hu, Z. Size dependent and reactive oxygen species related nanosilver toxicity to nitrifying bacteria. Environ. Sci. Technol. 2008, 42, 4583-4588. [CrossRef] [PubMed]

42. Priester, J.H.; Stoimenov, P.K.; Mielke, R.E.; Webb, S.M.; Ehrhardt, C.; Zhang, J.P.; Stucky, G.D.; Holden, P.A. Effects of soluble cadmium salts versus CdSe quantum dots on the growth of planktonic Pseudomonas aeruginosa. Environ. Sci. Technol. 2009, 43, 2589-2594. [CrossRef] [PubMed]

43. Gou, N.; Onnis-Hayden, A.; Gu, A.Z. Mechanistic toxicity assessment of nanomaterials by whole-cell-array stress genes expression analysis. Environ. Sci. Technol. 2010, 44, 5964-5970. [CrossRef] [PubMed]

44. Klaine, S.J.; Alvarez, P.J.J.; Batley, G.E.; Fernandes, T.F.; Handy, R.D.; Lyon, D.Y.; Mahendra, S.; McLaughlin, M.J.; Lead, J.R. Nanomaterials in the environment: Behavior, fate, bioavailability, and effects. Environ. Toxicol. Chem. 2008, 27, 1825-1851. [CrossRef] [PubMed] 
45. Dhas, S.P.; Shiny, P.J.; Khan, S.; Mukherjee, A.; Chandrasekaran, N. Toxic behavior of silver and zinc oxide nanoparticles on environmental microorganisms. J. Basic Microbiol. 2014, 54, 916-927. [CrossRef] [PubMed]

46. Tong, T.; Shereef, A.; Wu, J.; Binh, C.T.T.; Kelly, J.J.; Gaillard, J.-F.; Gray, K.A. Effects of material morphology on the phototoxicity of nano- $\mathrm{TiO}_{2}$ to bacteria. Environ. Sci. Technol. 2013, 47, 12486-12495. [CrossRef] [PubMed]

47. Marambio-Jones, C.; Hoek, E.M. A review of the antibacterial effects of silver nanomaterials and potential implications for human health and the environment. J. Nanopart. Res. 2010, 12, 1531-1551. [CrossRef]

48. Xie, Y.; He, Y.; Irwin, P.L.; Jin, T.; Shi, X. Antibacterial activity and mechanism of action of zinc oxide nanoparticles against Campylibacter jejuni. Appl. Environ. Microbiol. 2011, 77, 2325-2331. [CrossRef] [PubMed]

49. Lopes, S.; Ribeiro, F.; Wojnarowicz, J.; Lojkowski, W.; Jurkschat, K.; Crossley, A.; Soares, A.M.V.M.; Loureiro, A. Zinc oxide nanoparticles toxicity to Daphnia magna: Size dependent effects and dissolution. Environ. Toxicol. Chem. 2014, 33, 190-198. [CrossRef] [PubMed]

50. Vijver, M.G.; de Snoo, G.R. Toxicological mixture models are based on inadequate assumptions. Environ. Sci. Technol. 2010, 44, 4841-4842. [CrossRef] [PubMed]

51. Weaver, R.W.; Angle, S.; Bottomley, P.; Bezdicek, D.; Smith, S.; Tabatabai, A.; Wollum, A. Methods of Soil Analysis. Part 2; Microbiological and Biochemical Properties; Soil Science Society of America, Inc.: Madison, WI, USA, 1994.

52. Hadjispyrou, S.; Kungolos, A.; Anagnostopoulos, A. Toxicity, bioaccumulation and interactive effects of organotin, cadmium and chromium on Artemia franciscana. Ecotoxicol. Environ. Saf. 2001, 49, 179-186. [CrossRef] [PubMed]

(C) 2015 by the authors; licensee MDPI, Basel, Switzerland. This article is an open access article distributed under the terms and conditions of the Creative Commons by Attribution (CC-BY) license (http://creativecommons.org/licenses/by/4.0/). 